\title{
Analisis Dan Perancangan Proses Bisnis Dan Basis Data Untuk SIM (Sistem Informasi Manajemen) LSP AD
}

\author{
Novita Wulandari (10018062) ${ }^{1}$, Eko Aribowo (0006027001) ${ }^{2}$ \\ Teknik Informatika Universitas Ahmad Dahlan, Jl. Ringroad Selatan, Bantul, Yogyakarta 55191, Indonesia \\ ${ }^{1}$ vitawulan27@gmail.com; ${ }^{2}$ ekoab@tif.uad.ac.id
}

\begin{abstract}
ABSTRAK
Permasalahan yang dihadapi di LSP AD saat ini adalah proses sertifikasi profesi di LSP AD masih berjalan secara manual dalam artian peserta harus datang langsung ke LSP untuk proses sertifikasi profesi. Masalah kedua penyimpanan data masih berbentuk dokumen sehingga proses menjadi lama dan data kurang akurat. Kemudian batasan masalah sebatas analisis dan rancangan proses bisnis dan basis data pada unit bidang sertifikasi. Rumusan masalah penelitian berdasarkan pada bagaimana cara membuat rancangan sistem informasi manajemen sertifikasi profesi LSP AD menjadi lebih efisien.

Metode yang digunakan dalam penelitian ini yaitu metode wawancara (Interview) dan metode studi kepustakaan. Analasis dilakukan untuk menentukan spesifikasi perancangan agar sesuai kebutuhan. Perancangan menggunakan proses bisnis dan Basis data, untuk basis data rancangan yang dibuat yaitu flowcart, DFD, ERD, Mapping Tabel, Tabel Data, Perancangan Antar Muka(Interface). Pengujian dilakukan dengan cara kuesioner.

Hasil penelitian berupa analisis dan rancangan proses bisnis dan basis data untuk Sistem Informasi Manajemen LSP AD. Pada tugas akhir ini akan dijelaskan tentang pembuatan analisis dan rancangan sertifikasi profesi di LSP AD. Pada sistem pendaftaran, APL 01, APL 02, TUK dan pengumuman ini peserta dapat mengakses di web sedangkan untuk MUK(Materi Uji Kompetensi) peserta harus datang langsung ke LSP karena proses ini peserta akan di uji langsung oleh asesor. Hasil pengujian berdasarkan kuisioner yang diberikan pengurus LSP AD menyatakan bahwa analisis dan perancangan proses bisnis dan basis data yag dibuat sudah sesuai dengan SOP yang ada di UAD dan dapat digunakan untuk pengembangan LSP AD agar menjadi lebih baik.
\end{abstract}

Ciptaan disebarluaskan di bawah lisensi CC-BY-SA.

Kata kunci: Analisis, perancangan, proses bisnis, basis data, sertifikasi, LSP AD

\section{Pendahuluan}

Lembaga Sertifikasi Profesi Universitas Ahmad Dahlan (LSP UAD) atau disebut juga LSP AD, LSP AD adalah lembaga baru di UAD yang bertujuan untuk memenuhi tersedianya tenaga yang kompeten. LSP AD sendiri merupakan lembaga baru untuk melakukan proses pembuktian bahwa seorang tenaga yang profesional benar-benar kompeten dalam bidang kompetensinya. Sehingga tenaga profesional tersebut mendapatkan pengakuan Kompetensi Profesi yang dimilikinya baik secara Nasional ataupun Internasional [1].

Proses yang berjalan di LSP AD untuk sistem informasi manajemen saat ini adalah ketika peserta uji kompetensi mendaftar maka peserta harus melengkapi persyaratan yang sudah ditetapkan oleh LSP AD setelah persyaratan terpenuhi maka peserta akan diberikan oleh administrator form APL 01 jika form APL 01 sudah terpenuhi administrator akan mengarahkan peserta ke asesor untuk tahap pengisian form APL 02 berdasarkan dokumen peserta, asesor akan membuat keputusan apakah peserta tersebut dapat direkomendasikan untuk uji kompetensi, setelah dinyatakan dapat 
direkomendasikan maka peserta akan mengikuti tes tertulis dan wawancara. Berdasarkan laporan dan hasil rekomendasi oleh asesor selanjutnya LSP AD akan mengevaluasi, mempertimbangkan membuat keputusan sertikasi keputusan berupa pernyataan bahwa peserta diputuskan kompeten. Hasil keputusan sertifikasi diinformasikan kepada pihak-pihak yang relevan selambatnya 7(tujuh) hari kerja setelah keputusan sertifikat dibuat. Sertifikasi kompetensi dan surat keterangan kompetensi dikirimkan selambatnya 14 (empat belas) hari kerja setelah penyampaian hasil keputusan sertifikasi [1]

Perancangan proses bisnis diatas masih belum tersistemkan dengan baik karena proses mahasiswa yang mengikuti sertifikasi masih secara manual yang harus datang langsung ke LSP kemudian masalah kedua data dari mahasiswa yang mengikuti sertifikasi masih berbentuk file-file yang menumpuk berbentuk dokumen sehingga proses menjadi lama dan data kurang akurat maka dari itu akan dibuat proses bisnis dan basis data untuk menunjang standar mutu LSP AD menjadi lebih baik. Sehingga dapat mendorong LSP AD untuk perbaikan yang berkelanjutan di dalam sertifikasi kompetensi kerja dan menjamin pelaksanaan sertifikasi yang valid dan konsisten [1].

Unit-unit kerja yang ada di LSP AD yaitu :

1. Unit Bidang Sertifikasi

2. Unit Bidang Admistrasi dan Keuangan

3. Unit Bidang Komite Skema

4. Unit Bidang Pengujian Mutu.

Unit-unit inilah yang digunakan LSP AD menjadi proses mahasiswa untuk mendapatkan sertifikasi profesi yang berupa SPI (Surat Pendamping Ijasah) yang dapat digunakan mahasiswa sebagai tolak ukur kemampuan mahasiswa bahwa mahasiswa tersebut dinyatakan kompeten. Mahasiswa yang sudah dinyatakan kompeten harus memberi laporan kepada LSP AD minimal satu tahun satu kali, sehingga kompetensi pada profesionalismenya tetap tercatat dan diakui oleh LSP AD maupun BNSP [1]. Tetapi dalam tugas akhir ini unit kompetensi yang digunakan adalah Unit Bidang Sertifikasi.

Berdasarkan latar belakang masalah maka untuk mengatasi masalah proses sertifikasi kompetensi, penyimpanan dan pendataan pada sistem informasi manajemen(SIM) LSP AD, maka akan diajukan penelitian tugas akhir berjudul "Analisis dan Perancangan Proses Bisnis dan Basis Data Untuk SIM LSP AD” agar pengguna dari segi pemakai yaitu peserta dan dalam segi manajemen ada administrator, asesor, TUK, dan pejabat dapat lebih mudah dan akurat untuk proses sertifikasi kompetensi.

\section{Kajian Pustaka}

Penelitian ini mengacu pada beberapa penelitian sebelumnya yang berhubungan dengan objek pembahasan. Penelitian pertama mengacu pada Defransiko [6] mengatakan bahwa Sistem Informasi Akademik tidak berjalan dengan maksimal dikarenakan basis data yang sudah ada namun hanya digunakan untuk keperluan adminitrasi pembayaran biaya kuliah. Dengan semakin meningkatnya jumlah mahasiswa pada Universitas Baturaja, menjadikan basis data yang ada saat ini tidak memadai dan perlu perbaikan dan penambahan. Banyaknya data membuat besarnya data yang disimpan dalam basis data penyimpanan menjadi kurang efisien yang menyebabkan semakin sempitnya kapasitas media penyimpanan. Maka diperlukan penyesuaian tipe data dan relasi data diperlukan guna memperkecil terjadinya redudancy data dan mengurangi penyimpanan data-data yang sama pada beberapa tabel sehingga menjadikan penyimpanan lebih efisien. Sistem didefinisikan bagaimana memahami dan menspesifikasi dengan desain apa yang harus dilakukan oleh sistem. Sementara sistem desain diartikan sebagai menjelaskan dengan detail bagaimana bagian-bagian dari sistem informasi diimplementasikan.

Penelitian selanjutnya adalah penelitan oleh Desy [7] mengatakan untuk menjamin kinerja dosen sesuai dengan yang disepakati kontrak menejemen maka prodi TI harus melakukan penilaian kinerja dosen. Agar proses penilaian kinerja dosen terukur dan terstruktur dibutuhkan suatu proses bisnis. Oleh karena itu, Prodi TI perlu merancang suatu proses bisnis penilaian kinerja dosen, karena Prodi TI belum mempunyai proses bisnis penilaian kinerja dosen. Aktivitas 
penilaian kinerja dosen belum didokumentasikan ke suatu proses bisnis dan masih menjadi tacit knowledge. Oleh karena itu, aktivitas penilaian kinerja dosen tersebut dikonversi menggunakan knowledge conversion SECI. Hasil konversi SECI menghasilkan proses bisnis penilaian kinerja dosen. Proses bisnis ini diharapkan dapat menjadi panduan dan standar bagi Prodi TI dalam melakukan penilaian kinerja dosen.

Penelitian yang lain oleh Gufani [4] mengatakan PT Thamrin Brothers Palembang yaitu sebuah perusahaan dealer utama Yamaha terbesar yang menguasai area Sumatera Selatan dan Bengkulu. Besarnya biaya yang dikeluarkan saat mengadakan suatu kegiatan seringkali menjadi permasalahan di kantor pusat karena tidak terkoordinasinya kegiatan tersebut seringkali juga menghambat proses pemasaran dikarenakan lamanya proses approval dari kantor pusat. Maka perlu dibuat basis data yang tersentralisasi ke pusat guna memudahkan monitoring pemasaran dan mempercepat proses permintaan atau proposal pengajuan kegiatan sehingga kegiatan yang akan dilakukan oleh cabang menjadi lancar dan hasilnya dapat dengan cepat diketahui oleh kantor pusat.

Berdasarkan penelitian yang telah dipaparkan di atas, maka dilakukan penelitian lebih lanjut dengan judul "Analisis dan Perancangan Proses Bisnis dan Basis Data untuk SIM (Sistem Informasi Manajemen) LSP AD”. Sebuah sistem yang menghasilkan perancangan suatu proses bisnis yang terstruktur dan basis data sertifikasi bagi LSP AD sehingga mampu menghasilkan informasi berupa laporan ke LSP AD yang dapat mempermudah dalam penyimpanan catatan, penghapusan, pemeliharaan dan peng-update-an tenaga profesional LSP AD.

\section{Proses Bisnis}

Proses bisnis dapat didefinisikan sebagai kelompok dari keputusan-keputusan yang terkait dan kegiatan yang dibutuhkan untuk menelola sumber daya bisnis. Input dari proses bisnis dapat berupa material, peralatan, obyek terukur lainnya, ataupun berbagai macam informasi yang kemudian diubah menjadi sejumlah output yang diperlukan oleh penerima. Penerima terbagi menjadi pelanggan internal dan pelanggan eksternal. Penerima terbagi menjadi pelanggan internal dan pelanggan eksternal. Pelanggan internal dapat berupa departemen, kelompok, atau sejumlah peralatan dan mesin. Pelanggan eksternal adalah orang atau organisasi yang membayar untuk mendapatkan produk atau pelayanan yang diperlukan. Selain itu penerima juga dapat berupa lokasi tempat keluaran disimpan untuk kebutuhan yang akan datang. [8]

\section{Basis data}

Basis data terdiri atas 2 kata, yaitu basis dan data. Basis kurang lebih dapat diartikan sebagai markas atau gudang, tempat bersarang atau berkumpul. Sedangkan data adalah representasi fakta dunia nyata yang mewakili suatu objek seperti manusia, barang, hewan, peristiwa, konsep dan sebagainya. Basis data (database) dapat didefenisikan dalam sejumlah sudut pandang seperti: [5]

a. Himpunan kelompok data (arsip) yang saling berhubungan yang diorganisasi sedemikian rupa agar kelak dapat dimanfaatkan kembali dengan cepat dan mudah.

b. Kumpulan data yang saling berhubungan yang disimpan secara bersama sedemikian rupa dan tanpa pengulangan (redudancy) yang tidak perlu, untuk memenuhi kebutuhan.

c. Kumpulan file/tabel/arsip yang saling berhubungan yang disimpan kedalam media penyimpanan elektronik.

\section{Flawchart}

Flowchart adalah bagan-bagan yang mempunyai arus yang menggambarkan langkah-langkah penyelesaian suatu masalah. Bagan alir adalah bagan yang menunjukkan alir (flow) di dalam program atau prosedur sistem secara logika. Bagan alir digunakan untuk menggambarkan prosedur sistem baik sistem berjalan ataupun sistem yang akan diusulkan. [9]

\section{Data Flow Diagram (DFD)}


Data flow diagram/diagram aliran data $(D F D / D A D)$ secara grafikal mendeskripsikan proses data, aliran dari data dan penyimpanan data dalam sebuah organisasi atau sistem bisnis. Data flow diagram adalah model proses menggambarkan aliran data melalui sebuah sistem dan tugas atau pengolahan yang dilakukan oleh sistem. DFD digunakan untuk mendokumentasikan sistem yang ada serta untuk merencanakan dan merancang sistem yang baru. [3]

\section{Entity Relationship Diagram (ERD)}

Entity Relationship Diagram digunakan untuk menggambarkan struktur logical database dalam bentuk diagram. ERD menyediakan cara yang sederhana dan mudah untuk memahami berbagai komponen dalam desain database. [2]

\section{Mapping Table}

Mapping table adalah proses perubahan dari model data konseptual atau yang biasa dikenal dengan $E R D$ kedalam bentuk model data fisik. Setelah merancang model basis data dengan $E R D$ selanjutnya yaitu memetakkan entitas-entitas ataupun relasinya kedalam sebuah table. Mapping table mempunyai ketentuan yaitu setiap entitas pasti berubah menjadi table serta atributnya akan menjadi field dari table tersebut. Sedangkan relasi bisa berubah menjadi table dan bisa juga tidak. [9]

\section{Perancangan Antar Muka}

Antarmuka (Interface) merupakan mekanisme komunikasi antara pengguna (user) dengan sistem. Antarmuka (Interface) dapat menerima informasi dari pengguna (user) dan memberikan informasi kepada pengguna (user) untuk membantu mengarahkan alur penelusuran masalah sampai ditemukan suatu solusi. [10]

\section{Metode Penelitian}

\subsection{Pendahuluan}

Penelitian yang dibahas pada tugas akhir ini adalah menganalisa dan perancangan proses bisnis dan basis data diharapkan dapatkan mempermudah dalam pengembangan sistem informasi dan pengelolaan menejemen kegiatan di LSP AD yang mencakup seluruh aspek yang diperlukan untuk menentukan kompetensi seseorang. Stakeholder yang diteliti yaitu peserta uji kompetensi, administrator, manajer sertifikasi, asesor, dan direktur.

\subsection{Alat Penelitian}

Adapun dalam penelitian ini menggunakan alat-alat berupa perangkat keras dan perangkat lunak komputer.

\subsection{Tahap Pengumpulan Data}

Pada tahap ini dilakukan proses pengumpulan data yang akan melalui 2 tahapan. Metode pengumpulan data yang digunakan dalam pembuatan sistem ini adalah :

\section{Wawancara (Interview)}

Pengumpulan data dengan melakukan wawancara adalah percakapan yang dilakukan oleh dua pihak, yaitu pewawancara (interviewer) yang mengajukan pertanyaan dan terwawancara (interviewer) yang memberikan jawaban atas pertanyaan itu. Dengan mendapatkan data-data secara langsung dari sumber yang mengerti sehubungan dengan pengamatan, penulisan bertanya langsung dengan pihak-pihak yang terkait dalam memberikan informasi untuk LSP AD.

2. Studi Pustaka 
Pengumpulan data dengan membaca literatur berupa buku, makalah, artikel, jurnal serta mempelajari data-data yang mendukung dalam penyelesaian masalah serta berbagai topik yang memiliki kaitan dengan penelitian ini. Selain itu sumber lainnya berupa website yang berkaitan dengan topik penelitian.

\subsection{User Requirement}

User Requirment atau kebutuhan pengguna yaitu menjelaskan mengenai kemampuan software yang hendak dibangun dari sudut pandang user.

Dalam hal ini LSP AD kebutuhan pengguna yang akan digunakan adalah bagaimana perancangan proses bisnis dan basis data dengan melihat kondisi saat ini bagaimana mahasiswa yang mengikuti sertifikasi dalam proses mendaftar, TUK dan pengumuman harus datang langsung ke LSP AD, maka dibutuhkan analisis dan perancangan untuk mempermudah peserta. Kondisi ini yang harus dipenuhi sistem atau komponen sistem untuk memenuhi kontrak, standar dan spesifikasi agar LSP AD menjadi lebih baik.

\subsection{Kebutuhan Sistem}

Kegiatan dalam tahap ini adalah memahami dengan sesungguhnya kebutuhan dari sistem yang baru dan mengembangkan sebuah sistem yang memadahi kebutuhan tersebut. Kegiatan analisis ini mengacu pada hasil wawancara, dan studi pustaka yang telah dilakukan. Hasil dari analisis kebutuhan sistem ini dijadikan sebagai dasar untuk menentukan kebutuhan dari aplikasi yang perlu dikembangkan. Hasil dari analisis kebutuhan ini dibagi menjadi dua bagian yaitu analisis kebutuhan fungsional dan analisis kebutuhan non fungsional.

a. Kebutuhan Fungsional

b. Kebutuhan Non-fungsional

\subsection{Perancangan Sistem}

Pada tahap ini akan merancang suatu sistem berdasarkan hasil analisis sistem yang telah dilakukam, pada perancangan sistem mengembangkan spesifikasi teknis yang diperlukan untuk mengimplementasikan database program antar muka pengguna pada sistem ini. Pada tahap perancangan sistem yang dirancang antara lain :

1. Perancangan Proses Bisnis

2. Perancangan Flowchart

3. Perancangan DFD

4. Perancangan ERD

5. Perancangan Mapping Table

6. Perancangan Tabel data

7. Perancangan Antar Muka (Interface)

\subsection{Pengujian}

Tahapan ini dilakukan dengan penilaian menggunakan kuisioner untuk memberikan tanggapan apakah proses bisnis dan basis data tersebut telah sesuai dengan kebutuhan dari LSP AD. Dengan menjawab kuisioner dari daftar pertanyaan, diharapkan dapat mengevaluasi kekuatan dan kelemahan yang dimiliki oleh LSP AD serta peluang yang ada dan untuk mengevaluasi ancaman yang mungkin terjadi. 


\section{Hasil dan Pembahasan}

\subsection{Analisis LSP}

Lembaga Sertifikasi Profesi Universitas Ahmad Dahlan (LSP UAD) atau disebut juga LSP AD, LSP AD adalah lembaga baru di UAD yang bertujuan untuk memenuhi tersedianya tenaga yang kompeten. Dalam pengolahan data pendaftaran ujian sertifikasi profesi di Universitas Ahmad Dahlan atau LSP AD masih dilakukan secara manual dan pendaftar harus datang secara langsung ke tempat pendaftaran, selanjutnya data peserta akan disimpan kedalam sebuah arsip map yang nantinya data tersebut akan digunakan kembali untuk proses pembuatan laporan.

A. Identifikasi Kebutuhan Sistem Identifikasi data dan informasi

a) Identifikasi data yang digunakan :

1) Data peserta uji kompetensi

2) Data Administrator

3) Data Asesor

4) Data Pejabat sertifikasi

5) Data Jadwal

6) Data Pengumuman

7) Data Berita

b) Identifikasi informasi yang dihasilkan :

1) Laporan data peserta

2) Laporan data Administrator

3) Laporan data Asesor

4) Laporan data Pejabat Sertifikasi

5) Laporan data Jadwal

6) Laporan data Pengumuman

7) Laporan data Berita

8) Formulir Pendaftaran

c. Identifikasi Tujuan Informasi

1) Peserta ujian sertifikasi profesi

2) Pengelola ujian sertifikasi profesi di LSP AD

\subsection{Perancangan Sistem}

1. Perancangan Proses Bisnis

Proses bisnis adalah suatu proses yang menggambarkan alur kerja atau mekanisme kerja yang dilakukan oleh unit atau pihak - pihak terkait, dokumen atau data yang digunakan atau dihasilkan.

a. Proses Pendaftaran LSP AD dapat dilihat pada Gambar 1 dibawah ini : 


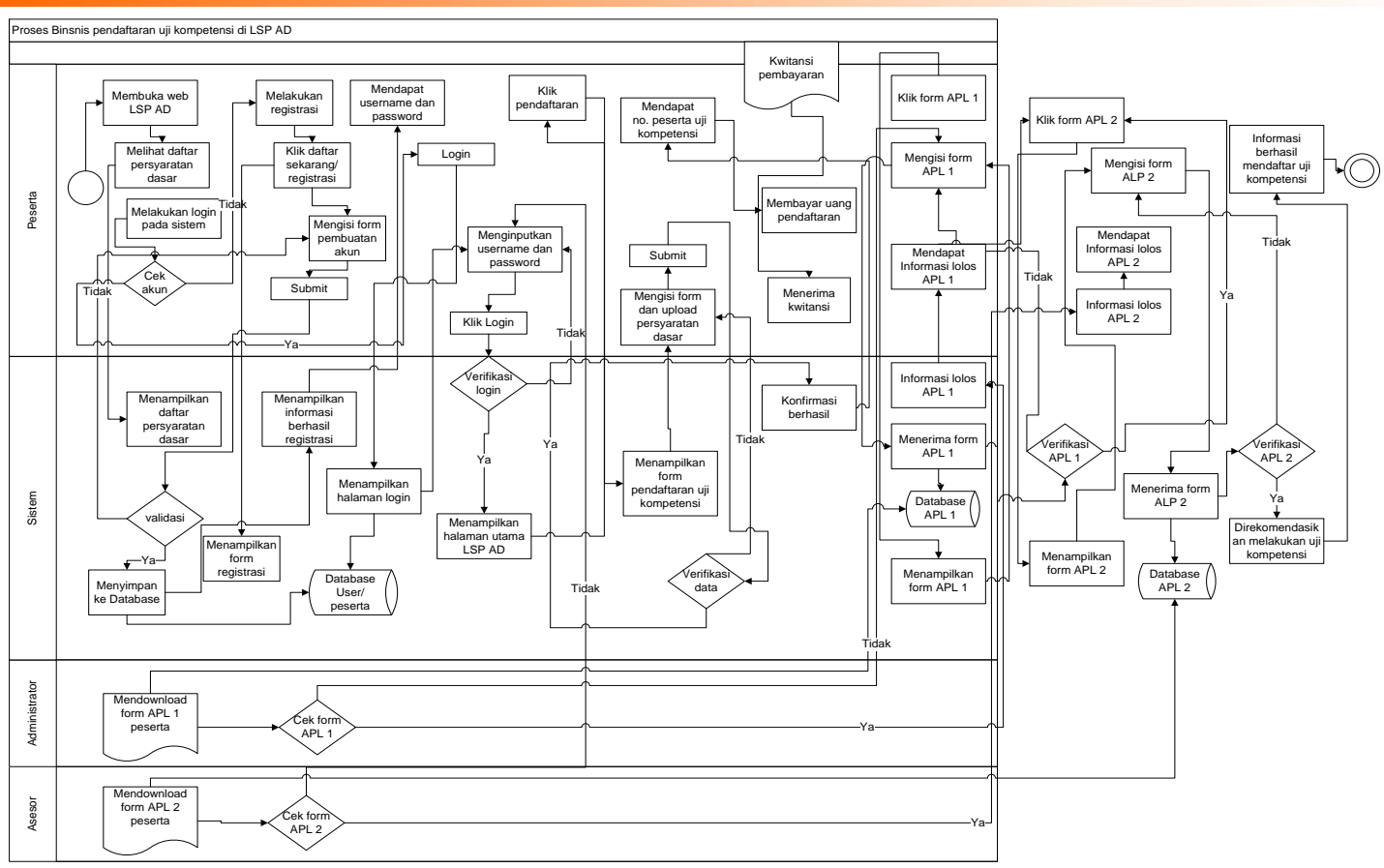

Gambar 1. Proses Bisnis Pendaftaran LSP AD

b. Proses Uji Kompetensi LSP AD dapat dilihat pada Gambar 2 dibawah ini :

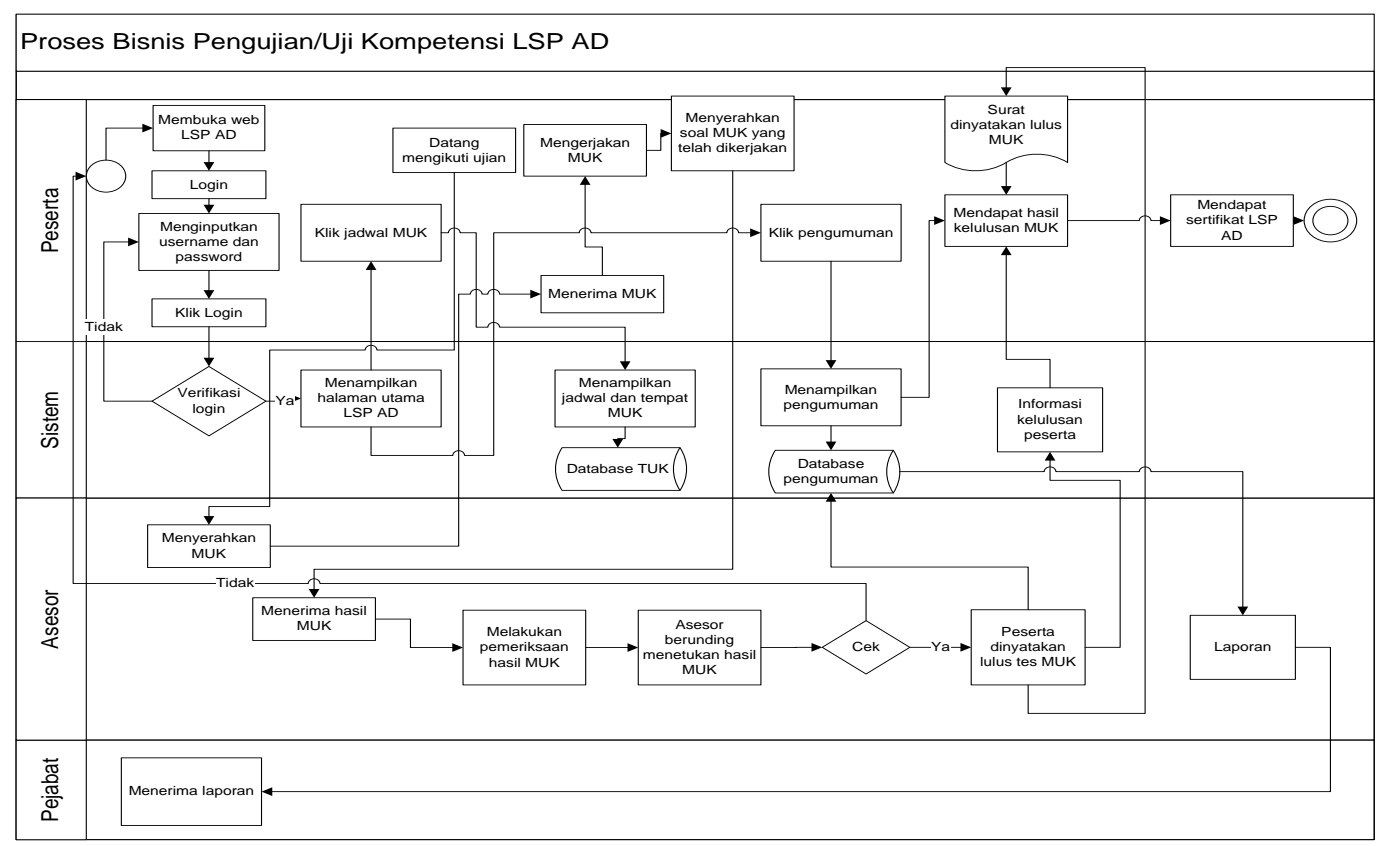

Gambar 2. Proses Bisnis Uji Kompetensi

\section{Perancangan Basis Data \\ a. Flowchart}

Flowchart disini menggambarkan proses-proses LSP AD sehingga mudah dipahami berdasarkan urutan proses ke proses lainnya. Serta dapat menyederhanakan proses LSP AD untuk memudahkan pemahaman terhadap sistem informasi. Berikut Flowchart LSP AD yang terdapat pada Gambar 3 dibawah ini : 


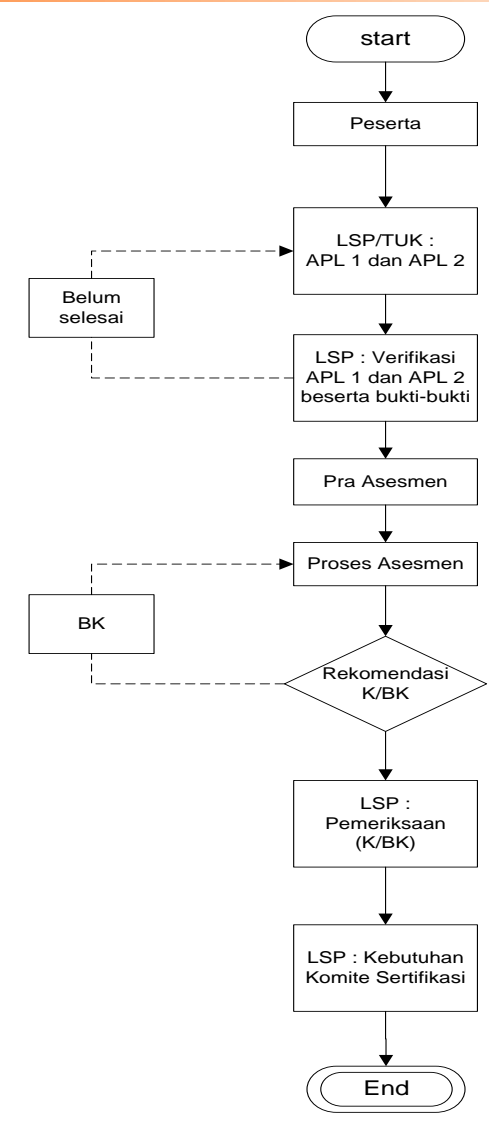

Gambar 3. Flowchart

b. Perancangan Aliran data

1. Diagram Konteks merupakan diagram yang menggambarkan aliran data secara garis besar yang direpresentasikan dengan lingkaran tunggal yang mewakili keseluruhan system. Diagram konteks LSP AD adalah sebagai berikut yang terdapat pada Gambar 4 :

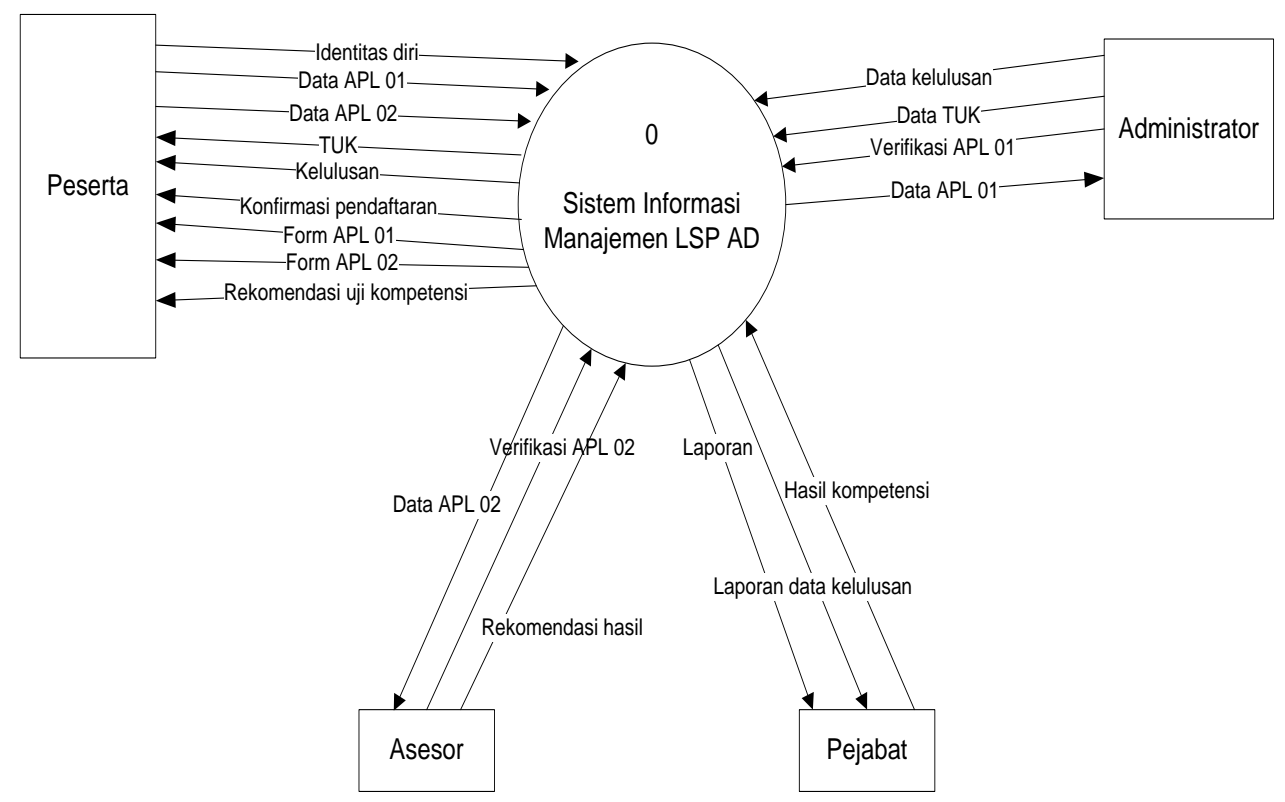

Gambar 4. Diagram Konteks 
2. Data Flow Diagram (DFD) yang dibuat sebagai dasar perancangan LSP AD yang dapat memperjelas proses-proses yang terdapat didalam sistem dimulai dari level 1, terdapat pada Gambar 5 adalah sebagai berikut :

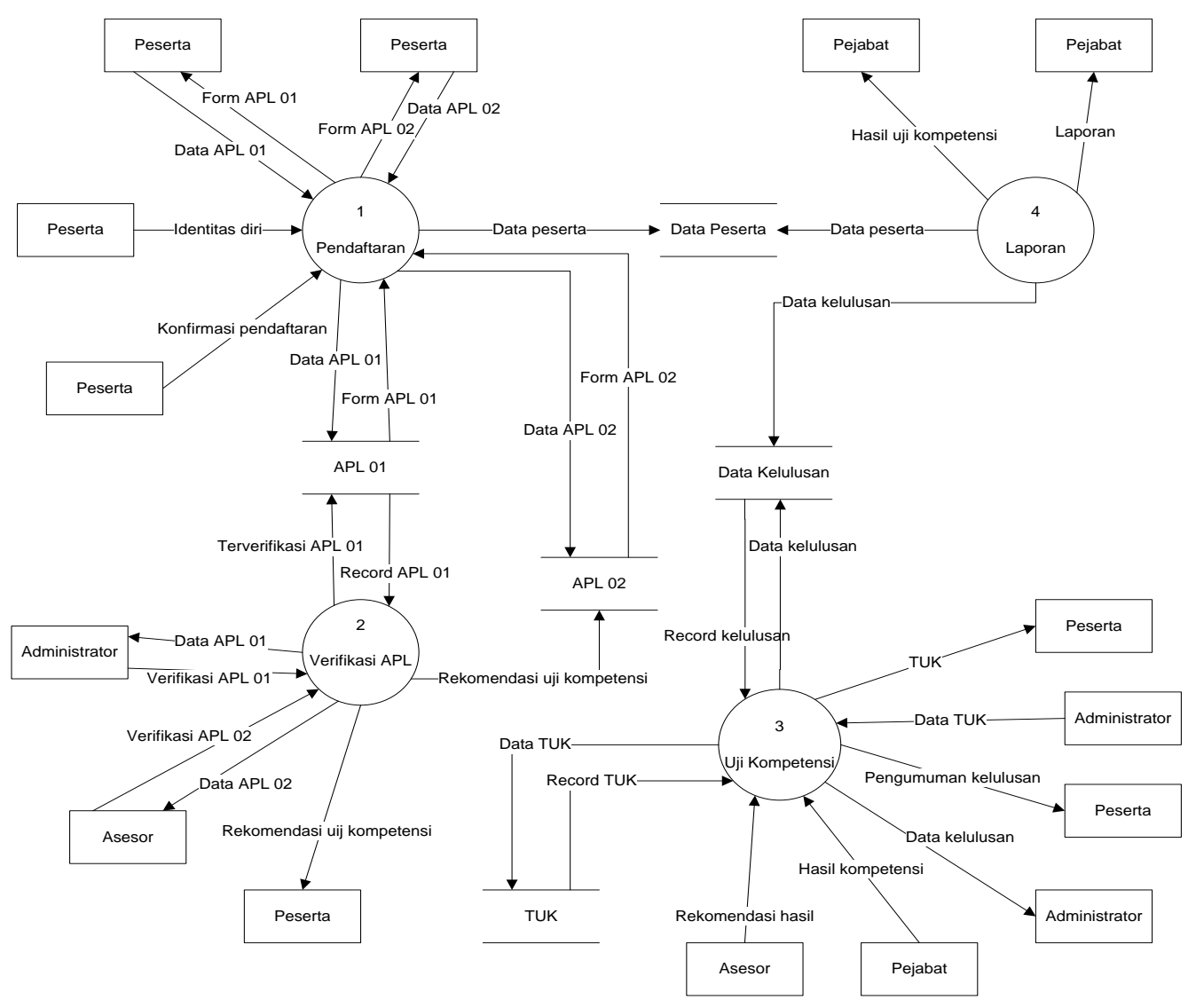

Gambar 5. DFD

\section{c. Perancangan ERD}

Entitas Relationship Diagram (ERD) biasanya digunakan untuk mengembangkan inisial dari desain basis data. Desain ERD menyediakan suatu konsep yang bermanfaat yang dapat mengubah deskripsi dari apa yang diinginkan oleh user menjadi hal yang lebih detail. ERD dapat dilihat pada Gambar 6 dibawah ini : 


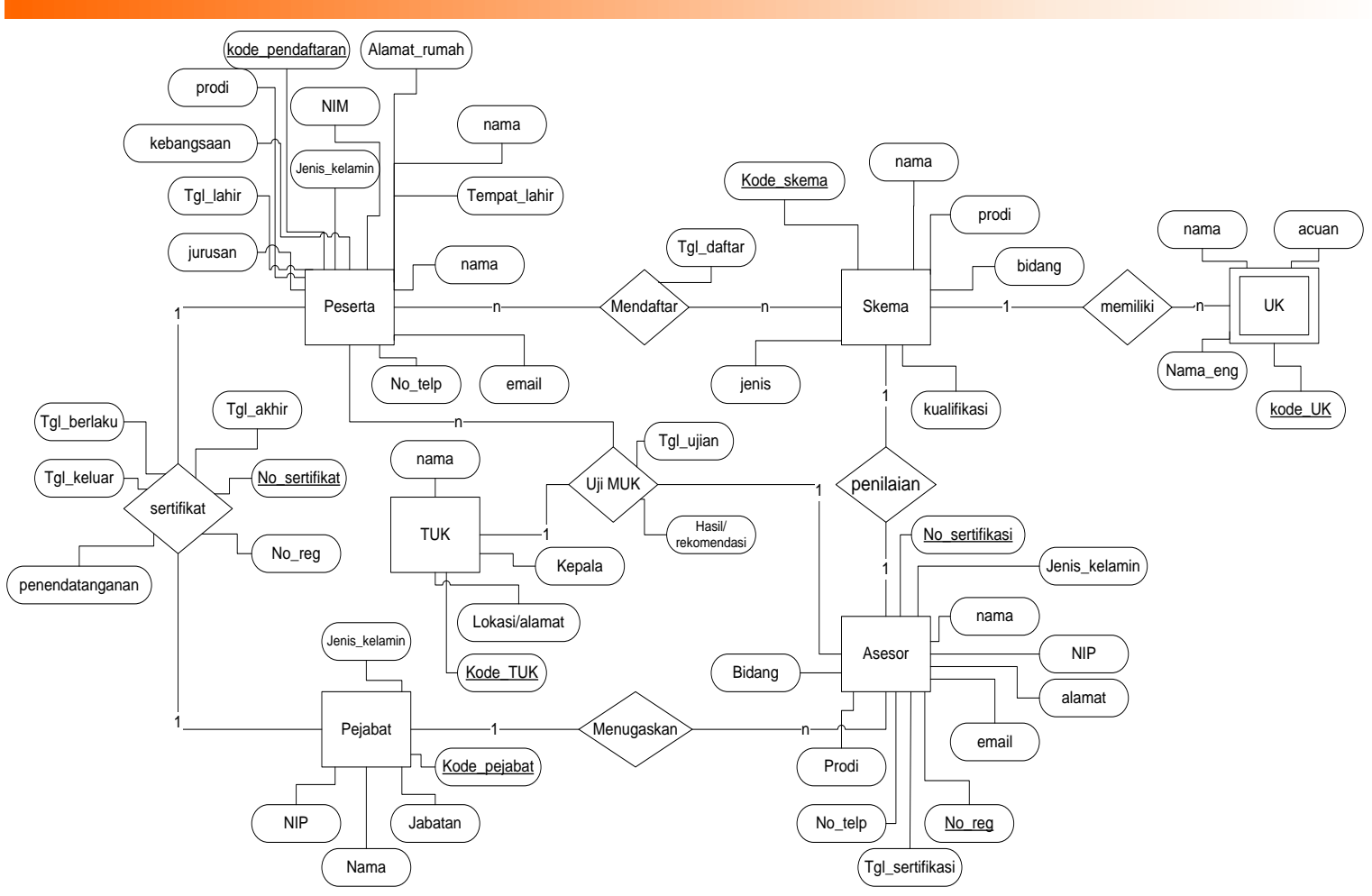

Gambar 6. ERD

\section{d. Mapping Table}

Mapping Table digunakan untuk meletakkan entitas-entitas ataupun relasi kedalam sebuah tabel karena mapping table mempunyai ketentuan yaitu setiap entitas pasti berubah menjadi tabel serta atributnya akan menjadi field dari tabel tersebut. Untuk menggambarkan hubungan antara field kunci (primary key) suatu tabel dengan field kunci utama (foreign key). Mapping Table LSP AD pada Gambar 7 berikut :

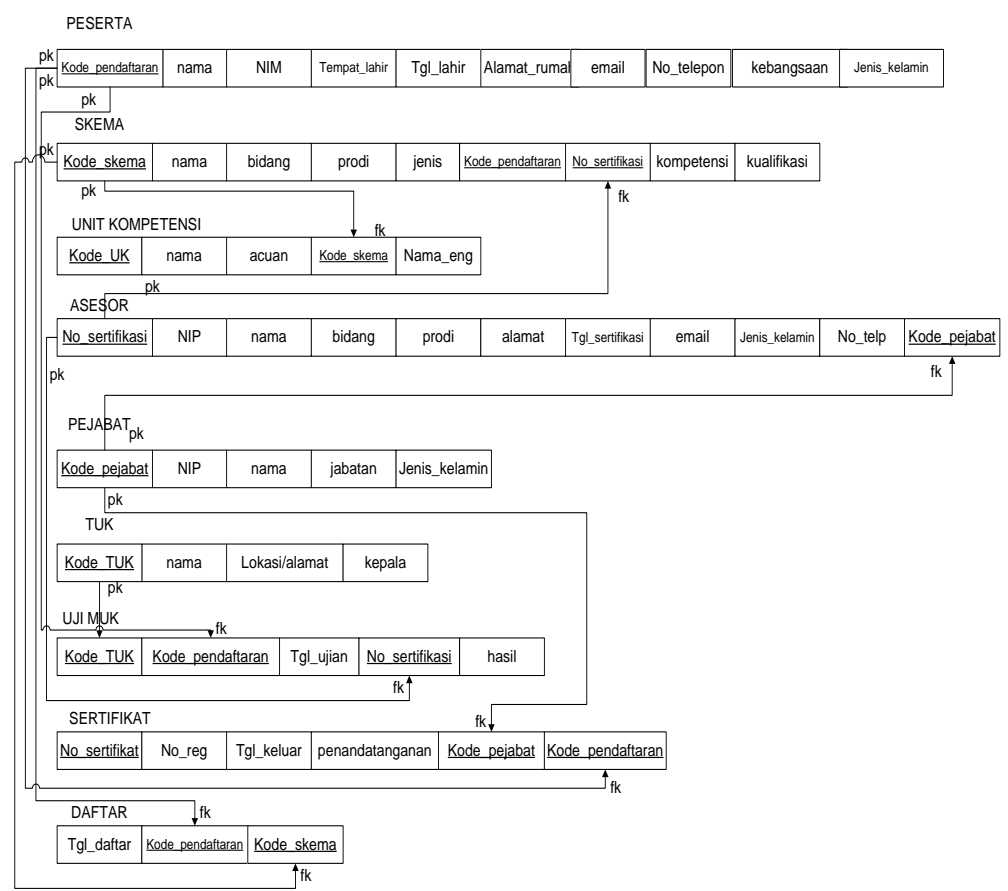

Gambar 7. Mapping Table 


\section{e. Pengujian}

Pada tahap pengujian dilakukan dengan cara menggunakan kuisioner untuk memberikan tanggapan apakah proses bisnis dan basis data telah sesuai dengan kebutuhan LSP AD. Hasil pengujian dengan cara menjawab Ya atau Tidak kepada para pengurus LSP AD, apakah proses bisnis dan basis data yang dibuat sudah sesuai dengan SOP yang ada di Universitas Ahmad Dahlan.

Dari hasil kuisioner yang diberikan kepada pengurus LSP AD menyatakan bahwa analisis dan perancangan proses bisnis dan basis data yag dibuat sudah sesuai dengan SOP yang ada di UAD dan dapat digunakan untuk pengembangan LSP AD agar menjadi lebih baik.

\section{Penutup}

\subsection{Kesimpulan}

Berdasarkan penelitian yang sudah dilakukan maka dapat disimpulkan beberapa hal sebagai berikut :

1. Penelitian ini menghasilkan analisis dan rancangan proses bisnis dan basis data SIM LSP AD. Hasil dari penelitian ini berupa rancangan proses bisnis, DFD, ERD, konseptual database dan rancangan user interface.

2. Perancangan proses bisnis dan basis data SIM(Sistem Informasi Manajemen) LSP AD menghasilkan suatu analisis dan rancangan proses bisnis dan basis data sertifikasi yang dapat menjadi panduan bagi para pelaku proses bisnis dan basis data dalam menjalankan proses sertifikasi.

\subsection{Saran}

Berdasarkan hasil penelitian ini maka dapat dikembangkan untuk membuat sistem terintegrasi atau menyeluruh pada SIM (Sistem Informsi Manajamen) LSP AD untuk meningkatkan pelayanan peserta uji kompetensi.

\section{Daftar Pustaka}

[1]BNSP, Pemerintah. (2014) "Pedoman Penilaian Lembaga Sertifikasi Profesi”. Peraturan Badan Nasional Sertifikasi Profesi : Jakarta.

[2] Connolly, T., Begg, C. (2010) Database Systems: a practical approach to design, implementation, and management. 5th Edition. America: Pearson Education.

[3] Dittman C,Kevin. (2004) MetodeDesaindanAnalisisSistem. Terjemahan oleh Tim PenerjemahANDI:Yogyakarta.

[4] Fatrin, Gufani. (2013) Analisis dan Perancangan Basis Data Terpusat Pemasaran Pada PT Thamrin Brothers Palembang. Skripsi. Palembang : Universitas Bina Darma.

[5] Fathansyah. (2012) Basis Data Edisi Revisi, Informatika : Bandung.

[6] Harapan, Defransiko. (2013) Analisis Perancangan Basis Data Akademik Universitas Baturaja. Skripsi. Palembang : Universitas Bina Darma.

[7] Hafriyani, Desy. (2015) Perancangan Proses Bisnis Penilaian Kinerja Dosen Menggunakan Metode Knowledge Conversion 5C-4C dan SECI. Skripsi. Bandung : Universitas Telkom.

[8] Harmon, Paul. (2007) "Business Process Change: A Guide for

[9] Janner,Simarmata.,Iman,Paryudi. (2006). Basis Data, EdisiPertama, Yogyakarta : Penerbit Andi.

[10] Whitten. (2004) Tahapan Proses Bisinis. Gramedia Pustaka Umum:Jakarta. 